\title{
Analisis Nilai Tambah Dan Pemasaran Produk Agroindustri Kelapa (cocos nucifera l.) Pada Perusahaan Wootay Coconut
}

\author{
Marfin Lawalata ${ }^{1^{*}}$ \\ Rika Imimpia ${ }^{2}$ \\ Program Studi Agribisnis, Fakultas Pertanian, Universitas Pattimura \\ email : marfinlawalata@gmail.com \\ Diterima: Februari 2020, Disetujui; April 2020, Dipublish: April 2020
}

\begin{abstract}
Abstrak
Perusahaan Wootay Coconut merupakan sebuah perusahaan yang bergerak dalam bidang produksi kelapa yang berdiri sejak tahun 2018. Proses produksi primer kelapa menjadi produk baru yang lebih tinggi nilai ekonomisnya setelah melalui proses pengolahan yang memberikan nilai tambah karena dikeluarkan biaya-biaya sehingga terbentuk harga baru dan keuntungan yang lebih besar bila dibandingkan tanpa proses pengolahan. Penelitian ini bertujuan untuk megetahui karakteristik, nilai tambah dan tingkat pendapatan perusahaan Wootay Coconut Kecamatan Teon Nila Serua Kabupaten Maluku Tengah. Metode yang digunakan adalah pengukuran nilai tambah berdasarkan metode Hayami, selanjutnya analisis pendapatan produk bahan baku kelapa. Hasil penelitian menunjukan bahwa nilai tambah pada kopra sebesar Rp.2.600,- rasio nilai tambah 42,62\%. Nata De Coco ukuran kecil nilai tambah sebesar Rp 311.100,- rasio nilai tambah 99,33\% sedangkan untuk ukuran besar nilai tambah sebesar Rp.296.191,68,- rasio nilai tambah 90,30\%. Virgin Coconut Oil (VCO) ukuran kecil sebesar Rp.515.250,- rasio nilai tambah 99,33\%, ukuran sedang nilai tambah sebesar Rp. 577.500,- rasio nilai tambah 99,40\% sedangkan ukuran besar nilai tambah sebesar Rp. 634.960,9,- rasio nilai tambah 99,45\% dari nilai produksi. Pendapatan Pada Perusahaan Wotay Coconut secara keseluruhan menghasilkan pendapatan bersih per bulan sebesar Rp. 55.117.833.
\end{abstract}

Kata kunci: Agroindustri-kelapa, nilai-tambah, pendapatan

\begin{abstract}
The Wootay Coconut Company is a company engaged in the field of coconut production which was established in 2018. The coconut production process changes the primary form into a new product with higher economic value after going through processing, and can provide added value due to costs incurred so that prices are formed new higher and greater profits when compared without going through processing. This research aims to determine the characteristics, added value and level of income of Wootay Coconut company, Teon Nila Serua Subdistrict, Central Maluku Regency. The method used is the measurement of added value based on the Hayami method, then the analysis of income for coconut raw material products. The results of the study showed that the added value in Copra was IDR 2,600, value added ratio of 42.62\%. Nata De Coco small size added value of IDR 311,100, - the ratio of value added 99.33\% while for large size added value of IDR 296,191.68, - value added ratio of 90.30\%. Virgin Coconut Oil (VCO) small size of IDR 515,250, - value added ratio of $99.33 \%$, medium size of value added of IDR 577,500, - the ratio of value added $99.40 \%$ while the large size of the added value of IDR 634,960.9, - value added ratio of 99.45\% of the production value. The overall income of the Wotay Coconut Company generates a monthly net income of IDR 55,117,833.
\end{abstract}

Keywords: Coconut-agro-industry, value-added, income. 


\section{PENDAHULUAN}

Tanaman kelapa (Cocos nucifera

L.) merupakan tanaman asli Indonesia dan tersebar hampir di semua wilayah di Indonesia. Tanaman kelapa dapat ditanam mulai dari dataran rendah hingga dataran tinggi mencapai 600 meter di atas permukaan laut. Tanaman kelapa (Cocos nucifera L.) merupakan tanaman yang sering dimanfaatkan sebagai sumber kehidupan masyarakat di Indonesia baik untuk bahan masak maupun bahan pokok industri.

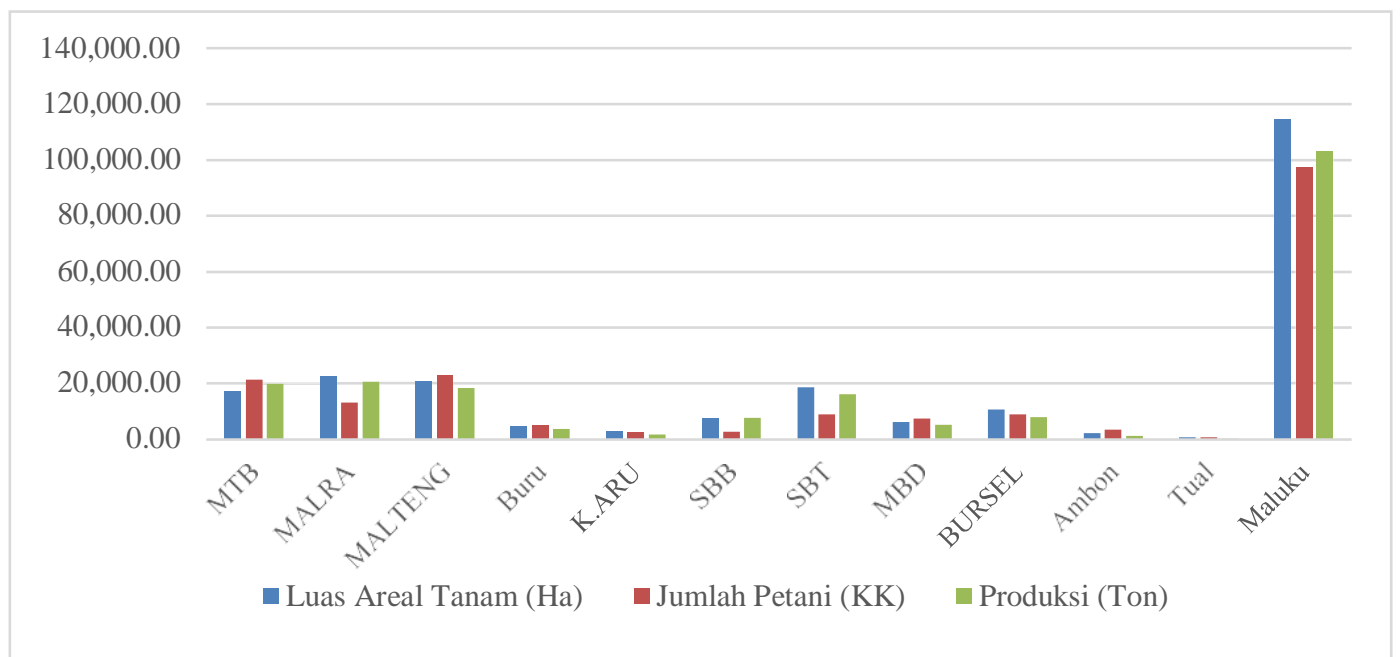

Gambar 1. Luas Areal Tanam (Ha), Jumlah Petani (KK) dan Produksi (Ton) Kelapa di Per Kabupaten Kota di Maluku Tahun 2018

Berdasarkan data Badan Pusat Statistik (BPS, 2018) luas lahan areal tanam di Maluku mencapai 114.561,60 Ha, dengan jumlah petani 97.293 kepala keluarga dan produksi mencapai 103.067,60 ton. Berdasarkan data pada gambar 1 diatas Kabupaten Maluku Tengah memiliki luas lahan kedua tertinggi di Maluku setelah Kabupaten Maluku Tenggara, namun memiliki jumlah petani lebih banyak dan produksi yang tidak berbeda jauh dengan Maluku Tenggara. Hal ini merupakan potensi yang dimiliki oleh Kabupaten Maluku Tengah. Namun, ketika ditelusuri produk olahan yang dihasilkan dan dipasarkan hanya sebatas kopra dan selebihnya kelapa dijual dalam bentuk segar di pasaran dengan harga jual Rp. 1.000,- s/d Rp. 1.500,-/ butir. Aspek agroindustri belum banyak diterapkan dalam meningkatkan nilai tambah tanaman kelapa yang melimpah di Maluku Tengah.

Desa Wootay yang terletak di Kecamatan Teon Nila Serua Kabupaten Maluku Tengah merupakan salah satu daerah penghasil kelapa, selain dari beberapa kecamatan lain yang juga penghasil kelapa seperti di Desa Layeni, dengan dua perusahaan 
pengelola kelapa yang juga memanfaatkan bahan baku kelapa, di Desa Wootay perusahaan pengelola kelapa dipandang sebagai perusahaan yang memiliki prospek usaha cerah dimasa depan oleh petani kelapa dengan diversifikasi produk memiliki nilai ekonomis tinggi, hal ini dikarenakan melipahnya bahan baku dan kemampuan menerima dan menerapkan inovasi dalam memproduksi berbagai produk agroindustri. Terdapat sekitar 40 persen kepala keluarga yang menggeluti usahatani dengan memanfaatkan buah kelapa untuk dijual tanpa memaksimalkan pengolahannya. Sebelumnya pengolahan kelapa yang dilakukan oleh masyarakat di daerah tersebut masih sangat kurang, sehingga diperlukan pengolahan yang lebih bermanfaat bagi masyarakat sekitar. Berdasarkan hasil wawancara dengan petani kelapa, pemanfaatan kelapa di Desa Wootay selama ini hanya sebatas pada pengolahan kelapa untuk dijadikan kopra, untuk jenis produk yang lain belum dikembangkan dengan maksimal sebelum adanya perusahaan Wootay Coconut di desa tersebut.

Agroindustri dipandang sebagai sub sistem yang penting dilakukan untuk meningkatkan nilai tambah, terutama pada saat produksi melimpah dan harga produk rendah, juga untuk produk yang rusak atau bermutu rendah maka disinilah saat yang tepat untuk mengolahnya lebih lanjut. Agroindustri dapat menjadi salah satu alternatif untuk meningkatkan perekonomian masyarakat, salah satunya industri pertanian yang kegiatannya terkait dengan sektor pertanian. Keterkaitan tersebut menjadi salah satu ciri dari negara berkembang yang strukturnya mengalami transformasi dari ekonomi pertanian (agriculture) menuju industri pertanian (agroindustry). Wujud keterkaitan ini adalah sektor pertanian sebagai industri hulu yang memasok bahan baku dan sektor industri pertanian sebagai industri yang meningkatkan nilai tambah pada hasil pertanian menjadi produk yang kompetitif (Herdiyandi, 2016).

Tanaman kelapa dapat didiversifikasi dalam berbagai bentuk mulai dari daun kelapa yang dapat dijadikan sebagai bahan pembuatan ketupat, batang dijadikan kayu, dan buah kelapa memiliki kegunaan diantaranya sabut kelapa dan tempurung dijadikan bahan bakar untuk pengasapan kopra dan juga kebutuhan masak rumah tangga. Daging kelapa juga dapat diolah menjadi minyak kelapa, VCO dan Nata De Coco. Selain itu juga yang nantinya dijual dan dipergunakan sebagai kebutuhan rumah tangga.

Perusahaan Wootay Coconut merupakan salah satu perusahaan yang bergerak dalam bidang agroindustri kelapa di Desa Wootay Kecamatan Teon Nila Serua Kabupaten Maluku Tengah. Perusahaan yang baru berumur dua 
tahun ini memiliki prospek yang cerah dan perkembangan yang pesat karena kemampuan manajerial dan diversifikasi produk yang dilakukan untuk menciptakan nilai tambah kelapa yang merupakan kekayaaan alam di Desa Wootay. Hal ini yang akhirnya menjadi bahan kajian dari penelitian ini selain prospek usaha yang cerah dan berkembang, perusahaan ini merupakan salah satu agroindusti skala menengah yang tetap survive terhadap usaha pengembangan agroindustri lainnya ditengah banyak sumber daya alam yang dapat dimanfaatkan ditunjang dengan kemampuan manajerial yang berpengalaman dari owner perusahaan itu sendiri.

Proses produksi kelapa mengubah bentuk primer menjadi produk baru yang lebih tinggi nilai ekonomisnya setelah melalui proses pengolahan, dan dapat memberikan Biasanya biaya-biaya itu lebih mudah ditentukan atau dinilai dari pada manfaat (Andayani, 2011). Setelah menghitung nilai tambah, identifikasi nilai biaya tetap dan biaya vaiabel, untuk mendapatkan nilai biaya variable sesuai persamaan berikut ini

$$
\mathrm{TC}=\mathrm{FC}+\mathrm{VC}
$$

Keterangan:

$\mathrm{TC}=$ Biaya total (Total Cost)

FC = Biaya tetap (Fixed Cost)

$\mathrm{VC}=$ Biaya variabel (Variable cost)

Biaya penyusutan peralatan dihitung dengan metode garis lurus dengan rumus sebagai berikut:

$$
\text { Penyusutan }=\frac{H P-N S}{\mathrm{n}}
$$

nilai tambah karena dikeluarkan biaya-biaya sehingga terbentuk harga baru yang lebih tinggi dan keuntungan yang lebih besar bila dibandingkan tanpa melalui proses pengolahan. Dengan demikian berdasarkan latar-belakang diatas, maka tujuan penelitian ini adalah mengkaji lebih lanjut tentang Nilai Tambah Agroindustri dan Pemasaran Kelapa (Cocos nucifera l.) pada Perusahaan Wootay Coconut Kecamatan Teon Nila Serua Kabupaten Maluku Tengah.

\section{METODE PENELITIAN}

Untuk menegtahui besarnya nilai tambah terhadap pengolahan buah kelapa menjadi kopra, Nata De Coco dan Virgin Coconut Oil (VCO), maka digunakan metode pengukuran nilai tambah yang dikemukakan Hayami dalam Sudiyono (2004)

$$
\begin{aligned}
& \text { Keterangan: } \\
& \text { HP = Harga perolehan (cost) } \\
& \text { NS = Nilai sisa (residu) } \\
& \text { n = Taksiran hasil produksi (unit) }
\end{aligned}
$$

\section{Penerimaan}

Menurut Soekartawi dalam Mugiono et al (2014), penerimaan usaha adalah perkalian antara produksi yang diproduksi dengan harga jual, pernyataan ini ditulis sebagai berikut:

$$
\text { TR }=\text { Y. Py }
$$

Keterangan:

$\mathrm{TR}=$ Total penerimaan (Total Revenue)

$\mathrm{Y}=$ Produksi yang diperoleh dalam usaha 
Py $=$ Harga

\section{Pendapatan}

Menurut Soekartawi dalam Mugiono et al (2014), pendapatan dihitung dengan menggunakan konsep pendapatan usaha yaitu selisih antara penerimaan dan semua biaya.

$$
\mathrm{Pd}=\mathrm{TR}-\mathrm{TC}
$$

Keterangan:

$\mathrm{Pd}=$ Pendapatan

$\mathrm{TR}=$ Total Penerimaan (Total revenue)

$\mathrm{TC}=$ Total Biaya $($ Total Cost $)$

\section{Pemasaran}

Menurut Kotler dan Keller (2007), saluran pemasaran adalah organisasi-organisasi yang saling tergantung yang tercakup dalam proses yang membuat produk atau jasa menjadi tersedia untuk digunakan atau dikonsumsi. Saluran pemasaran adalah perangkat jalur yang diikuti produk atau jasa setelah produksi, yang berkulminasi pada pembeli dan penggunaan oleh pemakai akhir.

Unsur-unsur dalam bauran pemasaran adalah product, price, promotion dan place, dan pemasaran produk dari perusahaan Wotaay Coconut dijelaskan dengan pendekatan 4P.

Dalam proses pemenuhan kebutuhan dan keinginan konsumen, perusahaan tidak akan mungkin melayani sendiri sebab setiap perusahaan mempunyai sifat yang komplek dan bersifat satu kesatuan. Hal ini dapat dilihat bahwa dalam suatu perusahaan terdapat berbagai macam kegiatan yang berbeda dimulai dari produksi, distribusi dan pemasarannya sehingga secara langsung diantara kegiatan itu saling berhubungan antara satu dengan yang lainnya.

\section{HASIL DAN PEMBAHASAN}

\section{Nilai Tambah Kelapa pada perusahaan Wootay Coconut}

Perusahaan Wootay Coconut merupakan salah satu perusahan yang menjalankan usaha agroindustri kelapa. Usaha ini dilakukan untuk mewujudkan nilai tambah tanaman kelapa yang melimpah, menciptakan lapangan kerja serta menghasilkan laba bagi perusahaan. Besarnya nilai tambah merupakan proses pengolahan yang didapat dari nilai produksi dikurangi dengan biaya bahan baku dan input lain terhadap nilai produk yang dihasilkan, tidak termasuk tenaga kerja. Berdasarkan gambar 2 dan hasil penelitian menunjukkan, bahwa Perusahaan

Wootay Coconut ini menghasilkan tiga macam produk yaitu Kopra, Nata De Coco dan Virgin Coconut Oil (VCO). Analisis perhitungan nilai tambah merupakan suatu metode yang digunakan untuk melihat besar produksi bahan bakudari usaha tersebut. Analisis nilai tambah berguna untuk menguraikan proses produksi menurut sumbangan masing-masing faktor produksi. Dasar perhitungan metode analisis nilai tambah ini menggunakan perhitungan Kg bahan baku kelapa. Nilai tambah kelapa dihitung 
berdasarkan

produksi.

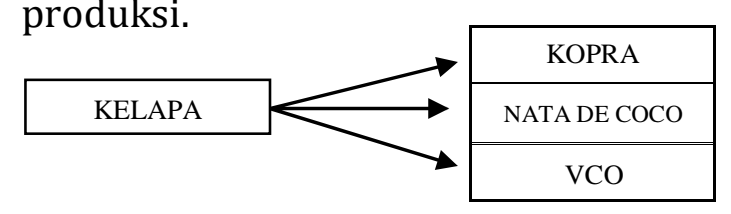

Gambar 1. Diversifikasi Produk Kelapa

\section{Nilai Tambah Produksi Kopra}

Output (produk olahan daging buah kelapa) yang dihasilkan yang pertama adalah kopra. Berikut adalah perhitungan nilai tambah kopra yang disajikan pada Tabel 2.

\section{dari Perusahaan Wootay}

Tabel 2. Nilai Tambah Kopra Pada Perusahaan Wootay Coconut

\begin{tabular}{clcc}
\hline \multirow{2}{*}{ No } & \multicolumn{1}{c}{ Uraian } & Satuan & Jumlah \\
\cline { 3 - 4 } & & & Kopra \\
\hline 1 & Hasil Produksi & $(\mathrm{kg})$ & 2.196 \\
2 & Bahan Baku : & & \\
& Daging Buah Kelapa & $(\mathrm{kg})$ & 1.440 \\
3 & Tenaga Kerja & $(\mathrm{HOK})$ & 96 \\
4 & Faktor Konversi & $(1: 2)$ & 1,525 \\
5 & Koefisien tenaga kerja & $(3: 2)$ & 0,066 \\
6 & Harga produk rata-rata & $(\mathrm{Rp} / \mathrm{Kg})$ & 4.000 \\
7 & Upah rata - rata & $(\mathrm{Rp} / \mathrm{HOK})$ & 15.625 \\
8 & Harga bahan baku & $(\mathrm{Rp} / \mathrm{Kg})$ & 3.500 \\
9 & Sumbangan input lain* & $(\mathrm{Rp} / \mathrm{kg})^{*}$ & 0 \\
10 & Nilai produk & $4 \times 6$ & 6.100 \\
11 & a. Nilai Tambah & $(10-9-8)(\mathrm{Rp} / \mathrm{kg})$ & 2.600 \\
& b. Rasio Nilai Tambah & $(11 \mathrm{a} / 10) \times 100 \%$ & $42,62 \%$ \\
12 & a. Imbalan Tenaga Kerja & $(5 \times 7)(\mathrm{Rp} / \mathrm{kg})$ & $1.031,25$ \\
& b. Bagian Tenaga Kerja & $(12 \mathrm{a} / 11 \mathrm{a}) \times 100 \%$ & $39,66 \%$ \\
13 & a. Keuntungan & $(11 \mathrm{a}-12 \mathrm{a})(\mathrm{Rp} / \mathrm{kg})$ & $1.568,75$ \\
& b. Tingkat Keuntungan & $(13 \mathrm{a} / 11 \mathrm{a}) \times 100 \%$ & $60,34 \%$ \\
\hline
\end{tabular}

Ket: * Bahan Penolong

Tabel 2 dapat dijelaskan bahwa nilai tambah yang diperoleh dari produksi kopra adalah sebesar Rp.2.600/kg. Nilai tambah ini diperoleh dari pengurangan nilai output (produksi kopra) dengan biaya bahan baku dan biaya bahan penunjang lainnya. Sedangkan rasio nilai tambah produksi kopra adalah sebesar $42,62 \%$, artinya $42,62 \%$ dari nilai output kopra merupakan nilai tambah yang diperoleh dari pengolahan agroindustri kopra.

Berdasarkan hasil penelitian analisis nilai tambah pengolahan Kopra di Desa Waepandan Kecamatan Kepala Madan Kabupaten Buru Selatan (Taipabu, 2018), untuk tingkat keuntungan lebih besar di Perusahaan Wootay Coconut dari 
pada di Desa Waepandan karena untuk bahan baku pada Desa Wootay lebih kecil dari pada bahan baku di Desa Waepandan, dan nilai tambah pada Desa Waepandan lebih besar dari Perusahaan Wootay Coconut karena upah tenaga kerja di Desa Wapandan lebih rendah, dibandingkan dengan Perusahaan Wootay Coconut. Hal ini dikarenakan bahan baku pada perusahaan yang didapatkan langsung dari petani, serta upah tenaga kerja yang diperoleh juga kecil karena penggunaan mesin peralatan pada perusahaan sehingga menekan upah tenaga kerja. Untuk tingkat keuntungan pada Perusahaan Wootay Coconut lebih besar dibandingkan tingkat keuntungan pada Desa Waepandan.

Hasil penelitian Neeke, et al (2015) menunjukkan pengolahan kelapa menjadi kopra di Desa Bolubung Kecamatan Bulagi Utara Kabupaten Banggai Kepulauan mampu memberikan nilai tambah sebesar Rp 955 per kilogram dengan nilai output sebesar Rp 1.260 dan nilai input Rp 305. Sedangkan Hasil penelitian Patty (2011) menunjukkan pengolahan kelapa menjadi Kopra di Kabupaten Halmahera Utara dapat memberikan nilai tambah yang relative kecil yaitu Rp 106 per kilogram. Berdasarkan hasil penelitian tersebut dapat diketahui bahwa nilai tambah Perusahaan Wootay Coconut lebih tinggi dari pada Desa Bolubung dan Kabupaten
Halmahera Utara yakni sebesar Rp 2.600 per kilogram.

\section{Nilai Tambah Produksi Nata De Coco}

Selain daging buah kelapa, air kelapa yang sering dianggap limbah dapat dimanfaatkan dengan mengolahnya menjadi Nata De Coco untuk meningkatkan nilai tambah. Produk Nata De Coco yang dihasilkan Wotay Coconut dua jenis Cup Kecil Seharga Rp. 1.500,- dan Cup Besar Rp. 5.000,- dan berikut adalah perhitungan nilai tambah Nata De Coco yang disajikan pada Tabel 3 nilai tambah yang diperoleh dari produksi Nata De Coco untuk harga Rp.1.500,adalah sebesar Rp.311.100/kg. Nilai tambah ini diperoleh dari pengurangan nilai output (produksi Nata De Coco) dengan biaya bahan baku dan biaya bahan penunjang lainnya. Sedangkan rasio nilai tambah produksi Nata De Coco adalah sebesar 99,33\%, artinya 99,33\% dari nilai output Nata De Coco merupakan nilai tambah yang diperoleh dari pengolahan agroindustri Nata De Coco.

Dalam penelitian Wardanu dan Uliyanti (2015) yang berjudul analisis nilai tambah dan kelayakan agroindustri Nata De Coco di Kabupaten Ketapang Kalimantan Barat untuk tingkat keuntungan lebih besar di Perusahaan Wootay Coconut dari pada di Kabupaten Ketapang karena untuk bahan baku pada Desa Wootay tidak membeli bahan baku 
karena diperoleh dari produksi Kopra dari pada Kabupaten Ketapang. Untuk nilai tambah pada Perusahaan Wootay Coconut lebih besar dibandingkan dengan Kabupaten Ketapang karena upah tenaga kerja untuk Perusahaan Wootay Coconut lebih kecil dibandingkan dengan Kabupaten Ketapang, dengan utilitas teknologi mesin dan peralatan pengolahan yang padat modal, penambahan produk agroindustri yang memiliki nilai jual oleh perusahaan.
Hasil penelitian diatas menunujukkan pengolahan kelapa menjadi Nata De Coco di Kabupaten Ketapang Kalimantan Barat mampu memberikan nilai tambah sebesar Rp. 3.340 per kilogram dengan rasio nilai tambah Nata De Coco sebesar 61\%. Berdasarkan hasil penelitian tersebut dapat diketahui bahwa nilai tambah Nata De Coco di Perusahaan Wootay Coconut lebih tinggi dibandingkan dengan Kabupaten Ketapang Kalimantan Barat.

Tabel 3. Nilai Tambah Nata De Coco Ukuran Kecil (Harga Jual Rp. 1.500,/Cup) pada Perusahaan Wootay Coconut

\begin{tabular}{clcc}
\hline \multirow{2}{*}{ No } & \multicolumn{1}{c}{ Variabel } & Satuan & Jumlah \\
\cline { 4 - 4 } & & & Nata De Coco \\
\hline 1 & Hasil Produksi & $(\mathrm{kg})$ & 2.088 \\
2 & Bahan Baku : & & \\
& Air Kelapa & $(\mathrm{kg})$ & 50 \\
3 & Tenaga Kerja & $(\mathrm{HOK})$ & 72 \\
4 & Faktor onversi & $(3: 2)$ & 41,76 \\
5 & Koefisien tenaga kerja & $(\mathrm{Rp} / \mathrm{Kg})$ & 1,44 \\
6 & Harga produk rata-rata & $(\mathrm{Rp} / \mathrm{HOK})$ & 7.500 \\
7 & Upah rata - rata & $(\mathrm{Rp} / \mathrm{Kg})$ & 20.833 \\
8 & Harga bahan baku & $(\mathrm{Rp} / \mathrm{kg})^{*}$ & 0 \\
9 & Sumbangan input lain* & $4 \times 6$ & 2.100 \\
10 & Nilai produk & $(10-9-8)(\mathrm{Rp} / \mathrm{kg})$ & 313.200 \\
11 & a. Nilai Tambah & $(11 \mathrm{a} / 10) \times 100 \%$ & 911.100 \\
& b. Rasio Nilai Tambah & $(5 \times 7)(\mathrm{Rp} / \mathrm{kg})$ & $29,33 \%$ \\
12 & a. Imbalan Tenaga Kerja & $(12 \mathrm{a} / 11 \mathrm{a}) \mathrm{x} 100 \%$ & $9,64 \%$ \\
& b. Bagian Tenaga Kerja & $(11 \mathrm{a}-12 \mathrm{a})(\mathrm{Rp} / \mathrm{kg})$ & $281.100,48$ \\
13 & a. Keuntungan* & $(13 \mathrm{a} / 11 \mathrm{a}) \mathrm{x} 100 \%$ & $90,36 \%$ \\
\hline
\end{tabular}

Ket: * Bahan Penolong

\section{Nilai Tambah Produksi VCo}

Selain menghasilkan output berupa kopra dan Nata De Coco, perusahaan juga menghasilkan Virgin Coconut Oil (VCO) dengan tiga ukuran (Kecil, Sedang dan Besar) namun 
yang ditampilkan hanya nilai tambah produk yang berukuran kecil dengan jangkauan harga serta jumlah produksi yang banyak bila dibandingkan dengan produk dengan dua ukuran lainnya, dengan harga jual Rp. 25.000,-/botol. Berikut adalah perhitungan nilai tambah produk VCO yang disajikan pada Tabel

Tabel 4. Nilai Tambah VCO Ukuran Kecil pada Perusahaan Wootay Coconut

\begin{tabular}{clcc}
\hline \multirow{2}{*}{ No } & \multicolumn{1}{c}{ Uraian } & Satuan & Jumlah \\
\cline { 4 - 4 } & & & VCO \\
\hline 1 & Hasil Produksi & $(\mathrm{kg})$ & 2.400 \\
2 & Bahan Baku : & & \\
& Daging Buah Kelapa & $(\mathrm{kg})$ & 1.440 \\
3 & Tenaga Kerja & $(\mathrm{HOK})$ & 96 \\
4 & Faktor Konversi & $(1: 2)$ & 1,66 \\
5 & Koefisien tenaga kerja & $(3: 2)$ & 0,066 \\
6 & Harga produk rata-rata & $(\mathrm{Rp} / \mathrm{Kg})$ & 312.500 \\
7 & Upah rata-rata & $(\mathrm{Rp} / \mathrm{HOK})$ & 15.625 \\
8 & Harga bahan baku & $(\mathrm{Rp} / \mathrm{Kg})$ & 3.500 \\
9 & Sumbangan input lain* & $(\mathrm{Rp} / \mathrm{kg})^{*}$ & 0 \\
10 & Nilai produk & $4 \times 6$ & 518.750 \\
11 & a. Nilai Tambah & $(10-9-8)(\mathrm{Rp} / \mathrm{kg})$ & 515.250 \\
& b. Rasio Nilai Tambah & $(11 \mathrm{a} / 10) \times 100 \%$ & $99,33 \%$ \\
12 & a. Imbalan Tenaga Kerja & $(5 \times 7)(\mathrm{Rp} / \mathrm{kg})$ & $1.031,25$ \\
& b. Bagian Tenaga Kerja & $(12 \mathrm{a} / 11 \mathrm{a}) \mathrm{x} 100 \%$ & $0,20 \%$ \\
13 & a. Keuntungan* & $(11 \mathrm{a}-12 \mathrm{a})(\mathrm{Rp} / \mathrm{kg})$ & $514.218,75$ \\
& b. Tingkat Keuntungan & $(13 \mathrm{a} / 11 \mathrm{a}) \mathrm{x} 100 \%$ & $99,80 \%$ \\
\hline
\end{tabular}

Ket: * Bahan Penolong

Berdasarkan Tabel 3 dapat dijelaskan bahwa nilai tambah yang diperoleh dari produksi VCO untuk harga jual Rp. 25.000,- adalah sebesar Rp.515.250/kg. Nilai tambah ini diperoleh dari pengurangan nilai output (produksi VCO) dengan biaya bahan baku dan biaya bahan penunjang lainnya. Sedangkan rasio nilai tambah produksi VCO adalah sebesar 99,33\%, artinya 99,33\% dari nilai output VCO merupakan nilai tambah yang diperoleh dari pengolahan agroindustri VCO.

Jika dibandingkan dengan hasil penelitian Setyawan dan Purwanti (2016) tentang nilai tambah dan profitabilitas komoditas kelapa di Kabupaten Natuna, untuk nilai tambah lebih besar di Perusahaan Wootay Coconut dari pada di Kabupaten Natuna yaitu sebesar Rp. 2.400,- karena harga bahan baku di Desa Wootay lebih murah yaitu sebesar RP. 1.440,-. Besarnya nilai 
tambah berbanding lurus dengan besarnya pendapatan pada Perusahaan Wootay Coconut yang lebih besar jika dibandingkan dengan usaha komoditas kelapa Kabupaten Natuna karena volume produksi di Perusahaan Wootay Coconut lebih besar dibandingkan dengan Kabupaten Natuna walaupun perusahaan ini tergolong masih baru beroperasi.

\section{Pendapatan yang di peroleh dari Perusahaan Wootay Coconut}

Pendapatan merupakan hasil penerimaan dari masing-masing produksi produk tersebut. Perusahaan Wootay Coconut memiliki 3 macam produk yang diusahakan dari bahan baku kelapa. Pada ketiga produk ini memiliki tingkat pendapatan yang sangat mengutungkan, hal ini dikarenakan pada lokasi perusahaan tepat berada di pusat tanaman kelapa dimana bahan baku yang diperlukan melimpah dan continyu. Berikut ini akan dilampirkan tingkat pendapatan pada Perusahaan Wootay Coconut.

Tabel 5. Tingkat Pendapatan Kopra /Bulan

\section{Pendapatan}

\section{Biaya Tetap dan Biaya Variabel}

Besarnya pendapatan perusahaan tergantung pada kapasitas produksi tiap produk/hari dan biaya yang dikeluarkan selama proses produksi baik biaya tetap maupun yang bersifat variabel, seperti dapat dilihat pada tabel dibawah ini:

Tabel. 5 Komponen Biaya Tetap dan Variabel

\begin{tabular}{l|l}
\hline $\begin{array}{l}\text { Komponen Biaya } \\
\text { Tetap }\end{array}$ & $\begin{array}{l}\text { Komponen Biaya } \\
\text { Variabel }\end{array}$ \\
\hline Biaya penyusutan & Biaya bahan baku, \\
peralatan, biaya & Biaya bahan \\
listrik. & tambahan, Upah \\
& tenaga kerja, Biaya \\
& bahan bakar, bahan \\
& pembungkus, dan \\
& transportasi \\
\hline
\end{tabular}

\section{Pendapatan dari Produk Kopra}

Pendaptan dari usaha kopra tergantung dari besarnya penerimaan dan biaya tetap. Penerimaan (TR) pada usaha kopra tergantung dari besarnya produksi.

\begin{tabular}{|c|c|c|}
\hline \multicolumn{3}{|c|}{ Produk Kopra } \\
\hline Penerimaan & & Rp 8.784.000 \\
\hline Total Biaya Variabel & Rp 5.232.500 & \\
\hline Total Biaya Penyusutan & 55.833 & \\
\hline Total Biaya Tetap & Rp 1.580 .000 & \\
\hline Total Biaya Pengeluaraan & & Rp 6.868.333 \\
\hline Pendapatan & & Rp 1.915.667 \\
\hline Sumber: Data Primer, 2019 (diolah) & Rp. 1.915.667,-. Jik & a dibandingkan \\
\hline
\end{tabular}


dengan produk lain yang dihasilkan oleh perusahaan, produk dari kopra berpenghasilan/ bulan yang rendah sehingga membuat Perusahaan 
Wootay Coconat menambahkan 1 produk dengan menggunakan air kelapa menjadi Nata De Coco.

\section{Pendapatan Pendapatan dari Produk Kopra}

Pendaptan dari usaha Nata De Coco tergantung dari besarnya penerimaan dan biaya tetap. Penerimaan (TR) pada usaha kopra tergantung dari besarnya produksi.

Tabel 6. Tingkat Pendapatan Nata De Coco/Bulan

\begin{tabular}{|c|c|}
\hline \multicolumn{2}{|c|}{ Produk Nata De Coco } \\
\hline Penerimaan & Rp 48.000.000 \\
\hline Total Biaya Variabel & Rp 2.364.500 \\
\hline Total Biaya Penyusutan & Rp 2.291667 \\
\hline Total Biaya Tetap & Rp 7.600.000 \\
\hline Total Biaya Pengeluaraan & Rp 12.156.167 \\
\hline Pendapatan & Rp 35.743.833 \\
\hline Sumber: Data Primer, 2019 (diolah) & \\
\hline $\begin{array}{l}\text { Tabel } 6 \text { menunjukkan tingkat } \\
\text { pendapatan pada produk Nata De } \\
\text { Coco menghasilkan nilai yang sangat } \\
\text { mengutungkan bagi perusahaan } \\
\text { Wotay Coconut. } \\
\text { pendapatannya } \\
\text { Rp.35.743.833,- hal ini karena bahan } \\
\text { baku yang digunakan diambil dari } \\
\text { hasil pembuatan produk Kopra. } \\
\begin{array}{l}\text { Dengan perusahaan mendapatkan } \\
\text { pendapatan yang memuaskan }\end{array}\end{array}$ & $\begin{array}{l}\text { sehingga perusahaan berinisiatif } \\
\text { untuk menambahkan satu produk } \\
\text { lagi yaitu Virgin Coconut Oil (VCO). } \\
\text { Pendapatan dari Produk Virgin } \\
\text { Coconut Oil (VCO) } \\
\text { Pendaptan dari usaha Virgin Coconut } \\
\text { Oil (VCO) tergantung dari besarnya } \\
\text { penerimaan dan biaya tetap. } \\
\text { Penerimaan (TR) pada usaha kopra } \\
\text { tergantung dari besarnya produksi. }\end{array}$ \\
\hline
\end{tabular}

Tabel 7. Tingkat Pendapatan Virgin Coconut Oil (VCO)/Bulan

\begin{tabular}{|c|c|c|}
\hline \multicolumn{3}{|c|}{ Produksi Virgin Coconut Oil (VCO) } \\
\hline Penerimaan & & Rp 44.000.000 \\
\hline Total Biaya Variabel & Rp 1 & 00.000 \\
\hline Total Biaya Penyusutan & $\mathrm{Rp}$ & 5.341667 \\
\hline Total Biaya Tetap & $\mathrm{Rp}$ & 7.600 .000 \\
\hline Total Biaya Pengeluaraan & & Rp 26.541.667 \\
\hline Pendapatan & & Rp 17.458.333 \\
\hline
\end{tabular}

Sumber: Data Primer, 2019 (diolah)

Tabel 7 menunjukkan tingkat pendapatan Virgin Coconut Oil (VCO) menghasilkan nilai sebesar Rp.17.458.333,-. Proses produksi
Kopra dan Virgin Coconut Oil (VCO) peralatan yang digunakan sama, namun produk yang dihasilkan dari Virgin Coconut Oil (VCO) mencapai 
nilai terbaik dari kopra, hal ini dikarenakan Virgin Coconut Oil (VCO) menjual dalam bentuk botol yang kecil, sedang dan besar, dengan kisaran harga botol kecilnya sebesar Rp. 25.000,- /botol, botol sedang sebesar Rp. 35.000,- sedangkan harga botol besar mencapai Rp. 50.000,-

/botol, karena harganya yang jual produk yang tinggi menjadikan produk ini memperoleh pendapatan yang cukup tinggi, sehingga perusahaan diharapkan dapat menaikan jumlah produksi.

Pada Perusahaan Wootay Coconut secara keseluruhan menghasilkan pendapatan bersih per bulan sebesar Rp. 1.915.667 + Rp. $35.743 .833+$ Rp. $17.458 .333=$ Rp.

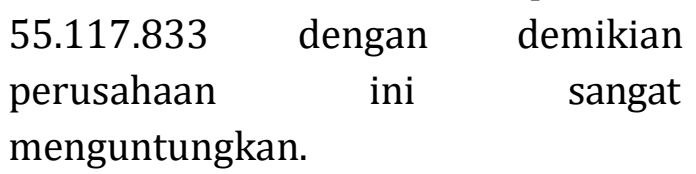

\section{Pemasaran}

Pemasaran adalah sistem pertukaran, artinya memperoleh barang dan jasa kemudian membayar dengan alat tukar (uang, cek dan sebagainya). Menurut Kotler (1995) bahwa saluran pemasaran atau distribusi adalah kegiatan pemasaran yang saling tergantung dalam proses mempermudah penyaluran produk dari produsen ke konsumen untuk digunakan atau dikonsumsi. Distribusi juga mampu menciptakan nilai tambah pada produk melalui fungsi-fungsi pemasaran yang dapat merealisasikan kegunaan atau utilitas bentuk, tempat, waktu dan kepemilikan. Saluran pemasaran pada Perusahaan Wootay Coconut ditampilkan pada Gambar 3.

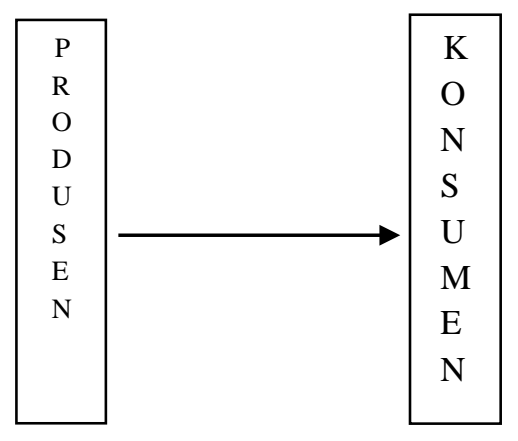

Gambar 3. Saluran pemasaran Perusahaan Wootay Coconut

Strategi pemasaran yang di pakai oleh Perusahaan Wootay Coconut atau yang dikenal dengan Bauran pemasaran antara lain:

a. Place/Distribution

Dalam memasarkan produknya, perusahaan harus mampu menentukan saluran distribusi yang akan digunakan untuk menyampaikan produknya kepada konsumen. Pemilihan saluran distribusi yang tepat akan memperlancar arus produk dari produsen kepada konsumen. Demikian sebaliknya, apabila ternyata dalam pemilihan saluran distribusi kurang tepat akan menghambat arus barang kepada konsumen, sehingga akan mengganggu kelangsungan kerja perusahaan. Sehingga Perusahaan Wootay Coconut dalam pelaksanaannya menggunakan saluran distribusi secara langsung yaitu dengan mengantarkan langsung ketempat konsumen. Dengan 


$\begin{array}{lrr}\text { memotong } & \text { saluran } & \text { distribusi } \\ \text { yang panjang } & \text { seperti } \\ \text { memasarkan langsung } & \text { ke } \\ \text { swalayan atau saluran yang } \\ \text { lainnya, sehingga dapat mencapai } \\ \text { efektifitas dan efesiensi } \\ \text { pemasaran. }\end{array}$

b. Promotion

Promosi yang dilakukan oleh Perusahaan Wootay Coconut adalah melalui media online misalnya melalui media sosial facebook, instagram, whatsapp dan mereka juga sering mengikuti pameran sekaligus untuk mempromosikan produk mereka.

c. Price

Harga menentukan besar kecilnya penerimaan yang diperoleh perusahaan produk yang dihasilkan bervariasi sehingga harga yang ditentukan juga beragam. Harga pada 3 produk yang dihasilkan perusahaan yaitu produk Nata De Coco dengan variasi produk dan rasa. Harga berkisar pada produk yang berukuran besar adalah Rp. 5.000,/gelas, berukuran sedang Rp. 3.000,-/gelas sedangkan produk dengan ukuran kecil adalah Rp. 2.000 ,-/gelas, dengan varian rasa Lemon, Coco pandan, leci dan melon. Produk Virgin Coconut Oil (VCO) sebagai produk dengan pendapatan tertinggi pada perusahaan, dengan ukuran variasi produk botol kecil adalah berkisar Rp. 25.000,-/botol, sedangkan ukuran sedangnya dijual Rp. 35.000,-/botol dan ukuran besar dijual dengan harga sebesar Rp. 50.000,-/botol. Sedangkan untuk produk kopra yang dihasilkan adalah berkisar dengan harga Rp. $4.000,-/ \mathrm{Kg}$. Untuk produk yang memiliki lebih dari satu ukuran misalnya Nata de Coco dengan tingkat harga yang berbeda bertujuan untuk menarik minat kosumen, selain itu agar lebih kompetitif dan bertujuan untuk market share.

d. Product

Produk yang dihasilkan oleh Perusahaan Wootay Coconut adalah produk Kopra, Nata De Coco dan Virgin Coconut Oil (VCO), semua produk itu dibuat dari bahan baku kelapa. Diversifikasi produk bertujuan untuk meningkatkan nilai tambah dan pendapatan. Terkait dengan logo, merk dan kemasan setiap produk yang dihasilkan diupayakan memiliki merk dagang dan kemasan yang menarik, bahkan untuk produk Nata de Coco perusahaan memproduksi beberapa ukuran dan kemasannya pun disesuaikan, sedangkan untuk logo perusahaan sudah memiliki logo yang paten yang sering dicantumkan pada produk yang dihasilkan.

\section{SIMPULAN}

Nilai tambah yang tercipta pada pengolahan Kelapa menjadi Kopra sebesar Rp.2.600,- rasio nilai tambah 42,62\%. Nata De Coco ukuran kecil nilai tambah sebesar Rp 311.100,- 
rasio nilai tambah 99,33\% sedangkan untuk ukuran besar nilai tambah sebesar Rp.296.191,68,- rasio nilai tambah 90,30\%. Virgin Coconut Oil (VCO) ukuran kecil sebesar Rp.515.250,- rasio nilai tambah 99,33\%, ukuran sedang nilai tambah sebesar Rp. 577.500,- rasio nilai tambah 99,40\% sedangkan ukuran besar nilai tambah sebesar Rp. 634.960,9,- rasio nilai tambah 99,45\% dari nilai produksi.

Pendapatan Pada Perusahaan Wotay Coconut secara keseluruhan menghasilkan pendapatan bersih per bulan sebesar Rp. $1.915 .667+$ Rp. $35.743 .833+$ Rp. $17.458 .333=$ Rp.

$\begin{array}{lrr}55.117 .833 & \text { dengan } & \text { demikian } \\ \text { perusahaan } & \text { ini } & \text { sangat } \\ \text { menguntungkan. } & & \end{array}$

\section{DAFTAR PUSTAKA}

Andayani. 2011. The Contribution of Individualism Vs. collectivism To Cross- National Differences In Display Rules. Asian Jurnal of Social Psychology 1: 147 - 168.

BPS, 2018. Luas Areal dan Produksi Tanaman Perkebunan Rakyat Tanaman Kelapa ". Dinas Pertanian Provinsi Maluku (Provinsi Maluku Dalam Angka). Herdiyandi, H. Rusman, Y. Yusuf, M. N. 2016. Analisis Nilai Tambah Agroindustri Tepung Tapioka di Desa Negaratengah Kecamatan Cineam Kabupaten Tasikmalaya. Jurnal Ilmiah
Mahasiswa Agroinfo Galuh vol-2 (2) : 81-86

Kotler \& Keller. 2007. Manajemen Pemasaran. Jakarta. Salemba Empat.

Mugiono A., T. Arlianti, dan A. Chotimatul. 2014. Panduan Lengkap Jamur. Jakarta. Penebar Swadaya

Neeke, H., Antara, M. \& Laapo, A. 2015. Analisis Pendapatan dan Nilai Tambah Kelapa Menjadi Kopra di Desa Bolubung Kecamatan Bulagi Utara Kabupaten Banggai Kepulauan. e-J. Agrotekbis. 3 (4) : 532-542.

Taipabu, L. I. F., Saediman., Fika, S.A. 2018. Analisa Nilai Tambah Pengolahan Kopra Di Desa Waepandan Kecamatan Kepala Madan Kabupaten Buru Selatan. Jurnal Ilmiah Agribisnis (JIA) 3 (3): 74-78.

Patty, Z. 2011. Analisis Produktivitas dan Nilai Tambah Kelapa Rakyat Studi Kasus di 3 Kecamatan di Kabupaten Halmahera Utara. Jurnal Agroforestri. 6 (2) : 153159.

Setyawan, S., Purwanti, E. 2016. Nilai Tambah dan Profitabilitas Komoditas Kelapa Di Kabupaten Natuna. UGM : 75-84.

Sudiyono, A. 2004. Pemasaran Pertanian. UMM Press. Malang.

Wardanu, A.P. \& Uliyanti. 2015. Analisa Nilai Tambah dan Kelayakan Agroindustri Nata De Coco di Kabupaten Ketapang Kalimantan Barat. Jurnal Teknologi dan Industri Pertanian Indonesia. 7 (2) : 44-47. 